\title{
CONTINGENT CLAIMS ANALYSIS OF SOVEREIGN DEBT SUSTAINABILITY IN ASIAN EMERGING MARKETS
}

Marie Brière, Benno Ferrarini, and Arief Ramayandi

NO. 486

June 2016
ADB ECONOMICS WORKING PAPER SERIES 


\section{Contingent Claims Analysis of Sovereign Debt Sustainability in Asian Emerging Markets}

Marie Brière, Benno Ferrarini, and Arief Ramayandi

No. 486 | June 2016
Marie Brière (marie.briere@dauphine.fr) is affiliate professor at the Paris Dauphine University and senior associate researcher at the Center Emile Bernheim, Université Libre de Bruxelles. Benno Ferrarini (bferrarini@adb.org) and Arief Ramayandi (aramayandi@adb.org) are senior economists at the Economic Research and Regional Cooperation Department, Asian Development Bank.

The authors would like to thank Dennis Sorino and Heili Bravo for excellent research assistance and the participants of the ERCD Seminar series for thoughtful comments. 
(c) 2016 Asian Development Bank

6 ADB Avenue, Mandaluyong City, 1550 Metro Manila, Philippines

Tel +63 2632 4444; Fax +6326362444

www.adb.org

Some rights reserved. Published in 2016.

Printed in the Philippines.

ISSN 2313-6537 (Print), 2313-6545 (e-ISSN)

Publication Stock No. WPS168152-2

Cataloging-In-Publication Data

Asian Development Bank.

Contingent claims analysis of sovereign debt sustainability in Asian emerging markets. Mandaluyong City, Philippines: Asian Development Bank, 2016.

1. contingent claims analysis. 2. public debt sustainability. I. Asian Development Bank.

The views expressed in this publication are those of the authors and do not necessarily reflect the views and policies of the Asian Development Bank (ADB) or its Board of Governors or the governments they represent.

ADB does not guarantee the accuracy of the data included in this publication and accepts no responsibility for any consequence of their use. The mention of specific companies or products of manufacturers does not imply that they are endorsed or recommended by ADB in preference to others of a similar nature that are not mentioned.

By making any designation of or reference to a particular territory or geographic area, or by using the term "country" in this document, $A D B$ does not intend to make any judgments as to the legal or other status of any territory or area.

This work is available under the Creative Commons Attribution 3.0 IGO license (CC BY 3.0 IGO) https://creativecommons.org/licenses/by/3.0/igo/. By using the content of this publication, you agree to be bound by the terms of this license.

This CC license does not apply to non-ADB copyright materials in this publication. If the material is attributed to another source, please contact the copyright owner or publisher of that source for permission to reproduce it. ADB cannot be held liable for any claims that arise as a result of your use of the material.

Attribution - In acknowledging ADB as the source, please be sure to include all of the following information:

Author. Year of publication. Title of the material. (c) Asian Development Bank [and/or Publisher].

URL. Available under a CC BY 3.0 IGO license.

Translations-Any translations you create should carry the following disclaimer:

Originally published by the Asian Development Bank in English under the title [title] @ [Year of publication] Asian Development Bank. All rights reserved. The quality of this translation and its coherence with the original text is the sole responsibility of the [translator]. The English original of this work is the only official version.

Adaptations-Any adaptations you create should carry the following disclaimer:

This is an adaptation of an original Work (c) Asian Development Bank [Year]. The views expressed here are those of the authors and do not necessarily reflect the views and policies of ADB or its Board of Governors or the governments they represent. ADB does not endorse this work or guarantee the accuracy of the data included in this publication and accepts no responsibility for any consequence of their use.

Please contact publications@adb.org if you have questions or comments with respect to content, or if you wish to obtain copyright permission for your intended use that does not fall within these terms, or for permission to use the ADB logo.

Notes:

In this publication, "\$” refers to US dollars.

Corrigenda to ADB publications may be found at: http://www.adb.org/publications/corrigenda 


\section{CONTENTS}

TABLES AND FIGURES $\quad$ iv

ABSTRACT V v

$\begin{array}{ll}\text { I. INTRODUCTION } & 1\end{array}$

II. CONTINGENT CLAIMS ANALYSIS AND THE SOVEREIGN BALANCE SHEET 2

III. DATA AND SUMMARY STATISTICS 6

IV. $\quad$ DISTANCE TO DISTRESS, SENSITIVITY, AND SCENARIO ANALYSIS 8

A. Sensitivity Analysis $\quad 10$

B. Scenario Analysis: Implications of Exchange Rate Uncertainty 11

$\begin{array}{lll}\text { V. CONCLUSION } & 15\end{array}$

$\begin{array}{ll}\text { APPENDIXES } & 17\end{array}$

$\begin{array}{ll}\text { REFERENCES } & 25\end{array}$ 


\section{TABLES AND FIGURES}

\section{TABLES}

$1 \quad$ Consolidated Sovereign Balance Sheet 4

2 Descriptive Statistics of the Main Variables of Interest $\quad 7$

3 Correlation of 5-Year CDS Spreads with Distance to Distress 10

$4 \quad$ Sensitivity of the Distance to Distress to Three Alternative Scenarios 11

A1.1 Sensitivity Analysis of the Sovereign Balance Sheet and Debt Sustainability Indicators, Indonesia

A1.2 Sensitivity Analysis of the Sovereign Balance Sheet and Debt Sustainability Indicators, Republic of Korea

A1.3 Sensitivity Analysis of the Sovereign Balance Sheet and Debt Sustainability Indicators, Malaysia

A1.4 Sensitivity Analysis of the Sovereign Balance Sheet and Debt Sustainability Indicators, Philippines

A1.5 Sensitivity Analysis of the Sovereign Balance Sheet and Debt Sustainability Indicators, Thailand

A2.1 PRC Summary Statistics

A2.2 Sensitivity Analysis of the Sovereign Balance Sheet and Debt Sustainability Indicators, People's Republic of China

\section{FIGURES}

$1 \quad$ Asset Value and Probability of Default 2

2 Payoff Diagrams for Risky Debt = Default-Free Debt Plus Short Put Option 3

3 Payoff Diagrams for Risky Debt = Asset Minus Equity (Call Option) 3

$4 \quad$ Distance to Distress and 5-Year CDS Spreads 8

$5 \quad$ Exchange Rate Fan Charts 12

6 Distance to Distress Distribution Due to Exchange Rate Variation 14

$7 \quad$ Distance to Distress Distribution, Indonesia 15

A2 Distance to Distress and 5-Year CDS Spreads, People's Republic of China 21 


\begin{abstract}
Contingent claims analysis applied to Indonesia, Malaysia, the Philippines, the Republic of Korea, and Thailand shows no particular vulnerability to sovereign debt distress during recent years. However, the highly volatile "distance to distress" measure suggests that any of these countries may fall victim to a sudden loss in market confidence. For example, the value of Indonesia's sovereign assets dropped to just two standard deviations above its repayment obligations during the 2013 United States Federal Reserve taper tantrum, causing capital outflows and currency depreciation. Generally, we find that contingent claims analysis and market-based risk measures well complement conventional debt sustainability analysis for Asia.
\end{abstract}

Keywords: contingent claims analysis, public debt sustainability

JEL codes: E60, F34, G13, H63 


\section{INTRODUCTION}

This paper applies contingent claims analysis (CCA) to assess public debt sustainability of five Asian economies: Indonesia, Malaysia, the Philippines, the Republic of Korea, and Thailand. ${ }^{1}$ It forms part of an ADB research project exploring risk-adjusted public debt sustainability analysis (DSA) for Asian economies. Related project papers provided standard DSA and fan-chart debt ratio projections for Asian countries (Ferrarini and Ramayandi 2015) and reviewed risk-based fiscal analysis methods in the Asian context (Kopits, Ferrarini, and Ramayandi 2016). These papers confirmed the validity of standard public DSA as an assessment tool. To complement DSA's focus on macroeconomic and fiscal flows analysis with information about market sentiment and valuations, they suggested that analysts apply risk-based fiscal analytical methods.

Value at risk ( $\mathrm{VaR}$ ) and contingent claims analysis (CCA) are risk-based methods that have long been applied to the analysis of private sector risk and have recently been adapted to the assessment of sovereign fiscal sustainability. ${ }^{2} \mathrm{VaR}$ estimates the worse potential outcome of stochastic shocks on fiscal sustainability at a given confidence level. CCA derives the implied value of sovereign assets-thus "contingent claims" - from the market value of liabilities, to establish a sovereign's sustainability against a certain threshold of debt repayment obligations. ${ }^{3}$ Of the two, VaR analysis derives a fiscal sustainability indicator from a full evaluation of the assets and liabilities on a sovereign's intertemporal consolidated balance sheet. Particularly, the identification and valuation of sovereign assets involves high informational and computational costs. CCA's focus on the market valuation of sovereign liabilities rather than assets, which are less observable and more difficult to value, circumvents the heavy data requirements of $\mathrm{VaR}$. This makes CCA more readily applicable to the context of developing Asia and of emerging economies more broadly (Kopits, Ferrarini, and Ramayandi 2016). ${ }^{4}$

On this premise, this paper sets up the basic CCA framework for the five Asian emerging economies following mainly Gray, Merton, and Bodie (2007) and Gray and Malone (2008). We estimate the sovereign consolidated balance sheet and compute a risk-based fiscal sustainability indicator, which we then subject to scenario analysis to assess the implications of specific shocks to countries' macroeconomic and policy environment. We then use bootstrapped projections of exchange rates and the CCA framework to assess public debt sustainability in the countries studied.

Throughout the paper, emphasis is placed on providing a simple exposition of the basic intuitions underlying CCA. Details and specific aspects of analysis are relegated to appendices. Appendix 1 reports the detailed results of sensitivity analysis. Appendix 2 shows the findings on the People's Republic of China (PRC) and explains why data limitations prompted the authors to exclude this country from the sample of countries discussed in the main text. Appendix 3 provides guidance

Our analysis also includes the PRC. Results are shown in Appendix 2. However, due to data limitations on the one hand, and the low share of external debt out of the total government debt, CCA does not seem practicable in the case of the PRC.

2 For example, Barnhill and Kopits (2003) adapted the VaR method to calculate the effect of macroeconomic volatility of Ecuador's public sector intertemporal balance sheet. Da Costa, Caputo Silva, and Baghdassarian (2004) conducted VaR simulations for Brazil, and Adrogue (2005) applied the technique to compare public debt sustainability and fat-tail default risk facing Central American economies.

3 See Kopits, Ferrarini, and Ramayandi (2016) for a comparison of VaR and CCA methods.

4 Of course, the benefit of data parsimony comes at a cost, namely that the opportunity to estimate the probability of exact line items causing significant shocks a sovereign's asset valuation is foregone, and so is the feasibility to disentangle the sources of risk reflected in the synthetic CCA risk indicators. 
through the steps of implementation of CCA, from data collection to estimation, and to the interpretation of result. For a more thorough discussion of CCA and macrofinancial risk analysis, the reader is referred to Gray and Malone (2008) and related publications listed in the references section.

\section{CONTINGENT CLAIMS ANALYSIS AND THE SOVEREIGN BALANCE SHEET}

A contingent claim, such as an option, is a financial asset the payoff of which depends on the value of another financial asset. Merton $(1974,1977)$ models contingent claims as a generalization of the Black and Scholes (1973) and Merton (1973) option-pricing theory for the assessment of firms' credit risk.

Central to CCA is the concept of risk-adjusted balance sheet of firms, which derives the value of senior (debt) and junior (equity) liabilities from assets that are assumed to follow a stochastic process. Figure 1 illustrates the basic intuition underlying CCA. It shows that the default barrier is breached when the value of assets falls below the value of promised payments on debt (Gray and Malone 2012). The repayment of debt is thus considered risky, and the value of debt consists of its notional, default-free value, minus the expected loss component from default over some time horizon.

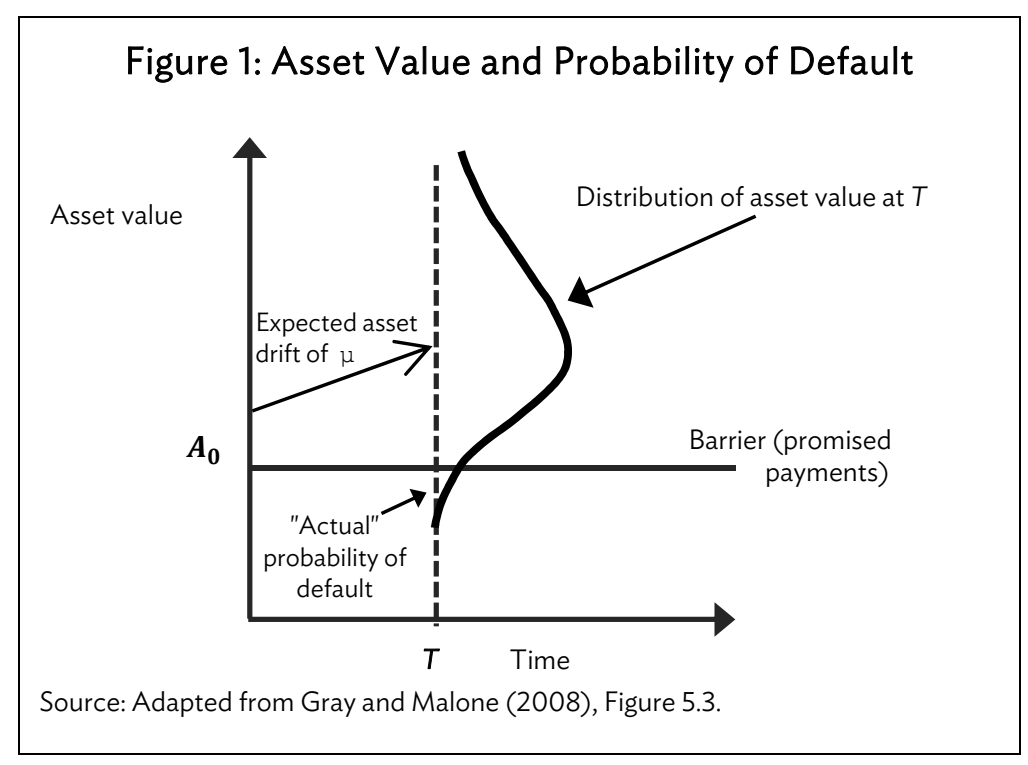

Merton's (1974) intuition is that the expected loss can be modeled as a put option on the value of the borrower's assets, with strike price equal to the promised payments of debt. The implications are illustrated in Figure 2, where the payoff structure of risky debt equals default-free debt plus the put option to account for the implicit default guarantee. By the same token, Figure 3 shows that a firm's equity can be modeled as a call option on the residual value of its assets, debt being the senior claim. Equity holders receive the difference between the value of assets and debt in case of no default, or will receive nothing in the case of default, when the full value of assets will have to pay off the holders of debt.

CCA is well established as a tool for assessing private firms' bankruptcy risk (Crosbie and Bohn 2003). Only recently has it been applied to the analysis of sovereign risk, as explored mainly by Dale Gray of the International Monetary Fund and a number of coauthored papers since the mid-2000s. Essentially, the sovereign version of CCA consolidates a country's balances akin to a firm's balance sheet, by distinguishing sovereign — rather than private-assets, debt, and equity. 


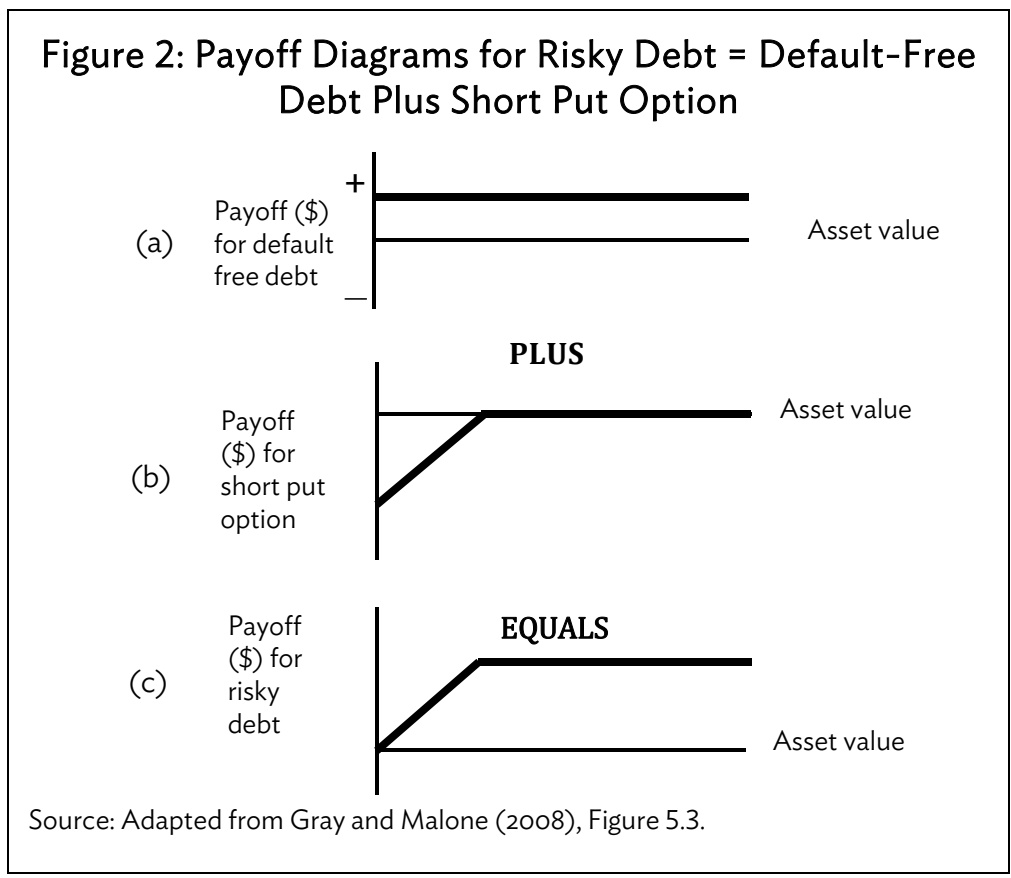

Figure 3: Payoff Diagrams for Risky Debt = Asset Minus Equity (Call Option)

(a)

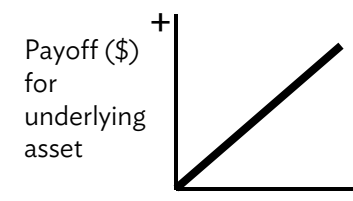

Asset value

(b)

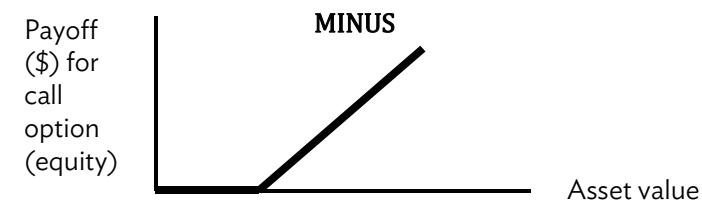

(c)

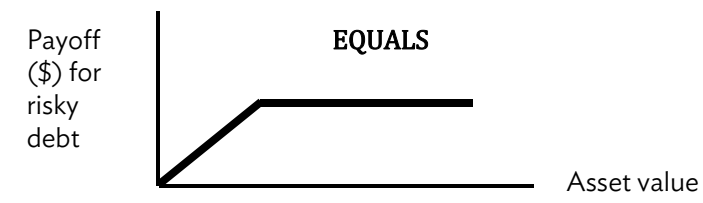

Source: Adapted from Gray and Malone (2008), Figure 5.2.

Local currency liabilities (domestic debt and money base) replace firm equity and are modeled as the junior claim. This rests on the assumption that countries will find it easier to restructure or issue local currency debt as opposed to restructuring foreign currency debt (IMF 2002). Just like a firm has the option to lower the value of equity by emitting more shares, a sovereign may choose to dilute local

5 For example, during the Ukraine (1998), Russian Federation (1999), or Argentinian (2001) debt restructuring, haircuts were much larger for domestic than international debt (Sturzenegger and Zettelmeyer 2008). A counterexample is the case of Uruguay (2003). 
currency-denominated debt by printing money. No such option exists for sovereign foreign currency debt, which thus constitutes the senior claim akin to a firm's "risky debt" in the CCA corporate framework.

Local currency liabilities constitute a call option on the country's assets, and the sovereign's distress barrier is simply assumed to be the book value of short-term foreign currency debt plus half the value of long-term foreign debt. Sovereign debt is deemed unsustainable as soon as the market value of sovereign assets falls short of the (present value of the flow of future) contractual obligations on debt. The lower or more volatile a sovereign's total assets, the higher its probability of default.

With this framework in place, CCA derives the value and volatility of sovereign assets from the liability side of the risk-adjusted balance sheet, which in turn is derived from the accounting balance sheet of the public sector and the central bank combined. Sovereign assets typically include international reserves; sovereign wealth fund assets; sovereign pension fund assets; other public sector assets (property, state-owned enterprises, etc.); as well as fiscal assets, such as the present value of the future flow of taxes and revenues.

On the other side of the consolidated sovereign balance sheet, liabilities mainly comprise the monetary base (MO); local currency-denominated debt; foreign currency-denominated debt; sovereign pension funds' liabilities; the present value of expenditures on economic and social development, security, government administration, and benefits to other sectors; the present value of target wealth to be left to future generations; as well as financial guarantees to the private sector (toobig-to-fail).

To derive the risk-adjusted consolidated balance sheet, a stylized version of which is shown in Table 1, too-big-to-fail guarantees are subtracted from the present value stream of income (on the assets side). Liabilities are rearranged as domestic liabilities ("equity") and foreign debt ("debt"), both expressed in foreign currency. They are valued as contingent claims on sovereign assets and modeled as options on the total value of the assets.

\section{Table 1: Consolidated Sovereign Balance Sheet}

\begin{tabular}{|l|l|}
\hline \multicolumn{1}{|c|}{ Assets } & \multicolumn{1}{c|}{ Liabilities } \\
\hline Foreign reserves, gold, special drawing rights & $\begin{array}{l}\text { Domestic liabilities: base money + local currency debt } \\
\text { ("equity") } \\
\text { Pension fund assets-liabilities }\end{array}$ \\
$\begin{array}{l}\text { Sovereign wealth fund assets } \\
\text { Other public sector assets (state-owned enterprises, real } \\
\text { estate) }\end{array}$ \\
$\begin{array}{l}\text { Present value of future income (taxes, fees, seigniorage) } \\
\text { minus present value of future expenditures on economic } \\
\text { and social development minus present value of target } \\
\text { wealth to be left to future generations minus financial } \\
\text { guarantees to too-big-to-fail institutions }\end{array}$ \\
\hline
\end{tabular}

Source: Adapted from Gray and Malone (2008), Figures 8.1 and 8.2. 
Specifically, if we consider a basic debt structure with two types of debt in zero-coupon form, domestic liabilities expressed in foreign currency terms $D L_{f}$ are defined as the sum of the monetary base and local debt expressed in foreign currency: ${ }^{6}$

$$
D L_{f}=\frac{M_{0}+B_{d}}{X}
$$

where $B_{d}$ is the market value of local debt; $M_{0}$ is the monetary base in local currency, and $X$ is the spot exchange rate.

Domestic liabilities are a call option on the value of sovereign assets $A_{f}$, expressed in foreign currency, with a strike price equal to the default barrier $B_{f}$. The latter is derived from payments promised in foreign currency until a time horizon $T{ }^{7}$ In theory, a sovereign's decision to default on debt depends on the perceived trade-off between short-run benefits and longer-run costs stemming from a loss of reputation for repayment (Eaton and Gersovitz 1981). In practice, governments' actions are revealed during distress episodes and past evidence forms the most reliable guide for identifying default barriers (Rogoff 2011). However, when historical evidence is scarce, CCA requires that the barrier be set at an arbitrary level, for example as the level of a countries' short-term foreign debt plus half their long-term foreign debt (as in Gray, Merton, and Bodie 2007 and Crosbie and Bohn 2003), or as the total short- and long-term foreign debt (as in Bodie and Brière 2014 and Duyvesteyn and Martens 2015). In this paper, we follow this latter method, as our data does not distinguish short-term from long-term debt.

As in Gray, Merton, and Bodie (2007), we assume that the value of sovereign assets $A_{f}$ and domestic liabilities $D L_{f}$ follows a lognormal diffusion process with constant volatility and risk-free rate. The value of domestic liabilities can then be computed using the Black and Scholes (1973) formulae, as in Merton (1974, 1977):

$$
D L_{f}=A_{f} N\left(d_{1}\right)-B_{f} e^{-r_{f} T} N\left(d_{2}\right)
$$

with $N($.$) the cumulative standard normal distribution, \sigma_{A}$ the volatility of the sovereign assets' returns.

$$
\begin{gathered}
d_{1}=\frac{\ln \left(\frac{A_{f}}{B_{f}}\right)+\left(r_{f}+\frac{\sigma_{A}^{2}}{2}\right) T}{\sigma_{A} \sqrt{T}} \\
d_{2}=d_{1}-\sigma_{A} \sqrt{T}
\end{gathered}
$$

For simpler notation, we omit subscript $t$, denoting time.

7 The choice of time horizon $(T)$ has a bearing on $d_{1}$ and $d_{2}$, which the below computations will keep fixed at 5 years. 
To find the values of the two unknowns $A_{f}$ and $\sigma_{A}$, equation (3) links the volatilities of sovereign assets and local currency liabilities $\sigma_{D L}$ (the junior claim). Assuming that the Black and Scholes assumptions hold, the following relationship applies: ${ }^{8}$

$$
D L_{f} \sigma_{D L}=A_{f} \sigma_{A}\left(d_{1}\right)
$$

With equation (1) determining the value of domestic liabilities, equations (2) and (3) solve to estimate the value of the sovereign's assets $A_{f}$ and their variance $\sigma_{A}^{2}$ as a function of the foreign debt default barrier $B_{f}$.

Term $\mathrm{d}_{2}$ of equation ( $2 \mathrm{a}$ ) represents the main debt sustainability indicator within the CCA framework, and is referred to as the distance to distress. It measures a country's distance from default as the difference between the implied market value of sovereign assets and the distress barrier, scaled by a one-standard-deviation move in sovereign assets. Put differently, it shows the number of standard deviations between a sovereign's assets value and distress.

With this simple framework in place, distance to distress can be estimated on the basis of a fairly limited amount of data, which we turn to next.

\section{DATA AND SUMMARY STATISTICS}

Data for Indonesia, Malaysia, the Philippines, the Republic of Korea, and Thailand are obtained from three sources:

(i) Bloomberg, for daily 5-year CDS spreads in the five countries, spot exchange rates of the five currencies versus United States (US) dollar and daily 5-year US government bond interest rate (Bloomberg government bond benchmark index).

(ii) Datastream, for the market value of government debt in local currency units, measured by the market capitalization of the JP Morgan GBI EM Index on a daily frequency, and domestic interest rates (yield to maturity) of the local currency debt index.

(iii) CEIC, for monthly series of monetary base (MO) and the monthly book value of foreign debt. Exceptions are the Republic of Korea and Malaysia, for which quarterly CEIC data have to be linearly interpolated in order to derive monthly frequencies.

We compute the volatility of the local currency liabilities as the annualized standard deviation of their daily returns over the past rolling 3 months. This keeps the indicator fairly stable while keeping it reactive to new information. ${ }^{9}$ To calculate a daily frequency series of local currency liabilities, we linearly interpolate the monthly frequency series of the monetary base and add it to the market capitalization of local debt, the latter being available on a daily basis from the JP Morgan government debt indices.

8 Black and Scholes (1973) assume that markets are efficient, no dividend is paid during an option's life, options are exercised at maturity, the absence of trading costs and taxes, constant volatility and interest rate, and that returns are lognormally distributed.

9 Robustness checks with a rolling 1-month standard deviation yield stable results. 
Table 2 lists the mean and standard deviation of the indicators used for the analysis. The two lines at the bottom of the table indicate the length of the country monthly time series in our sample, which is longest for Thailand (from October 2004) and shortest for the Republic of Korea (from December 2011). Compared to the value of local currency liabilities (the sum of the monetary base, $\mathrm{MO}$, and the market value of local debt, $\mathrm{Bd}$ ) the value of foreign debt ( $\mathrm{Bf}$ ) is less than $5 \%$ in the Republic of Korea and Thailand. Foreign debt is higher in Indonesia, at about $80 \%$ of total domestic currency debt, and at $40 \%$ in Malaysia. It is highest in the Philippines, exceeding local currency liabilities by a factor of more than three on average from January 2011 to August 2015.

Markets deemed all the five countries to be at a low risk of default over the sample period; CDS spreads are low on average, ranging between 21 basis points for the Republic of Korea to 45 basis points for Thailand. Also domestic interest rates are relatively low, at less than $4 \%$ in the Republic of Korea, Malaysia, and Thailand, and somewhat higher in the Philippines and Indonesia.

Exchange rate average returns vary greatly across countries, from $-0.4 \%$ in Indonesia to $0.1 \%$ in Thailand and the Republic of Korea. Volatilities range from $5.4 \%$ on Philippine foreign exchange returns, up to $7.7 \%$ in relation to Malaysia's ringgit.

Table 2: Descriptive Statistics of the Main Variables of Interest

\begin{tabular}{|c|c|c|c|c|c|c|}
\hline & & & Republic of & & & \\
\hline & & Indonesia & Korea & Malaysia & Philippines & Thailand \\
\hline $\mathrm{MO}$ & Avg & 30.12 & 47.90 & 16.48 & 12.33 & 25.63 \\
\hline$\$$ billion & St dev & 4.48 & 9.49 & 3.27 & 1.70 & 7.90 \\
\hline $\mathrm{Bd}$ & Avg & 49.63 & 338.58 & 64.26 & 2.89 & 38.69 \\
\hline \$ billion & St dev & 10.06 & 42.22 & 8.98 & 0.53 & 10.68 \\
\hline $\mathrm{Bf}$ & Avg & 62.33 & 7.35 & 35.16 & 54.17 & 2.84 \\
\hline \$ billion & St dev & 5.41 & 0.61 & 14.32 & 3.17 & 1.75 \\
\hline $\mathrm{Bf} /(\mathrm{MO}+\mathrm{Bd})$ & Avg \% & 78.16 & 1.90 & 43.55 & 356.01 & 4.42 \\
\hline CDS 5-year spread & Avg & 176.95 & 78.82 & 114.23 & 123.40 & 101.06 \\
\hline basis points & St dev & 38.95 & 32.90 & 45.13 & 36.85 & 56.89 \\
\hline Interest rate & Avg & 8.00 & 3.09 & 3.75 & 5.03 & 3.95 \\
\hline$\%$ & St dev & 1.35 & 0.45 & 0.28 & 0.66 & 0.84 \\
\hline FX spot rate & Avg & $10,275.80$ & $1,092.35$ & 3.27 & 43.36 & 33.81 \\
\hline value of $\$ 1$ & St dev & $1,520.81$ & 39.06 & 0.21 & 1.40 & 3.20 \\
\hline FX return & Avg & $-0.4 \%$ & $0.1 \%$ & $-0.2 \%$ & $-0.1 \%$ & $0.1 \%$ \\
\hline & Volatility & $7.2 \%$ & $7.0 \%$ & $7.7 \%$ & $5.4 \%$ & $6.0 \%$ \\
\hline First month & & 30-Jun-09 & 31-Dec-11 & 31-Mar-08 & 31-Jan-11 & $31-O c t-04$ \\
\hline Last month & & 31-Aug-15 & 30-Jun-15 & 30-Jun-15 & 31-Aug-15 & 31-Jul-15 \\
\hline
\end{tabular}

$B d=$ value of local debt, $B f=$ value of foreign debt, $C D S=$ credit default swap, $F X=$ foreign exchange, $M O=$ monetary base. Source: Authors' estimates. 


\section{DISTANCE TO DISTRESS, SENSITIVITY, AND SCENARIO ANALYSIS}

Based on the above data, we compute distance to distress according to the CCA framework laid out in section II. Results are plotted in Figure 4, together with 5-year CDS spreads for the five countries. For example, consider the first panel on Indonesia. The country's CDS spreads are seen hovering about the 150 basis points line-measured on the left axis - and occasionally jump up to nearly twice that level, such as in June 2009, when the global financial crisis hit Indonesia, and in June 2013, when capital outflows intensified against the backdrop of uncertainty in the Federal Reserve's (Fed) timing of interest rate hikes.

Figure 4: Distance to Distress and 5-Year CDS Spreads

(a) Indonesia

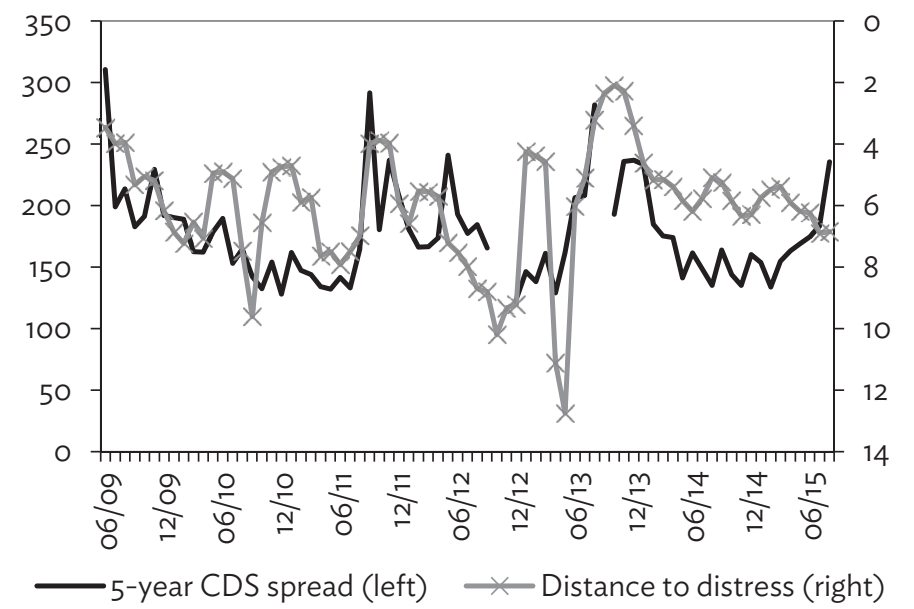

(b) Republic of Korea

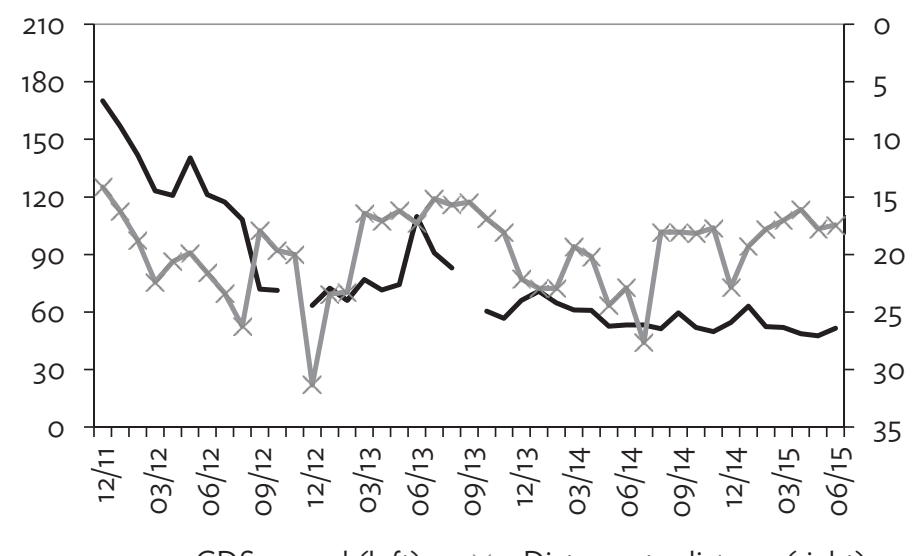

-5-year CDS spread (left) $\multimap$ Distance to distress (right) 


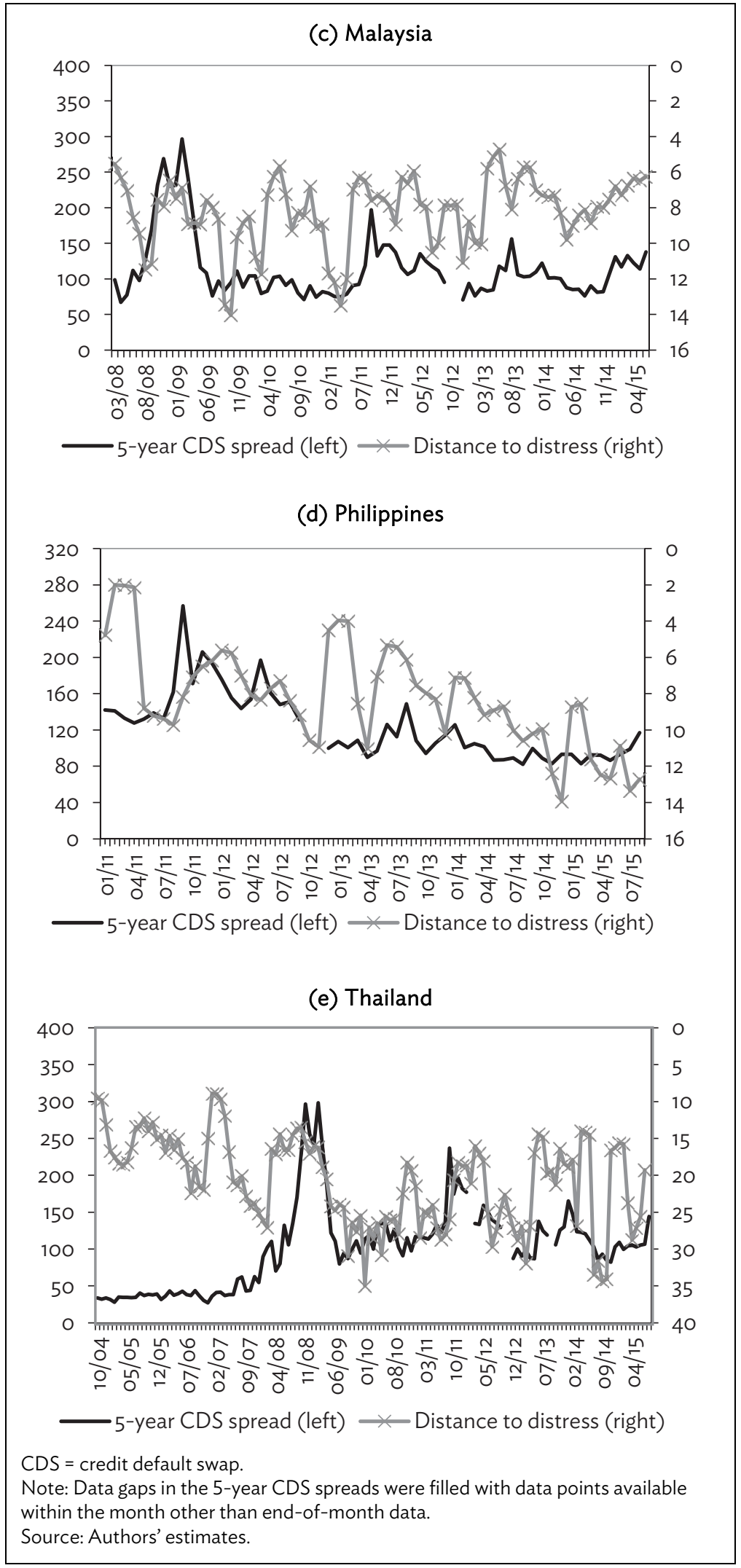


Distance to distress - measured on the right-hand side of the Indonesia chart- indicates the number of standard deviations the total value of Indonesia's sovereign assets exceeded the country's distress barrier. Over the 6 years shown on the chart, this distance measured about six standard deviations on average. This means that the likelihood of asset value breaching the distress barrier was very low. Only once over the entire period, in October 2013, did the distance to distress fall to two standard deviations only, signaling the market's diminished confidence in the country. This corresponds to the period of taper tantrum by the US Fed, causing heavy capital outflows from Indonesia and other emerging markets, combined with sharp exchange rate depreciations.

Figure 4 suggests that Indonesia and the other countries have been staying at a safe distance from distress. In the Republic of Korea and Thailand, this measure ranged between 15 and 30 standard deviations, and in Malaysia and the Philippines, it fluctuated at about half that level. In no instance during the period of observation would the distance to distress reading have raised red flags or signaled impending distress. However, the entire period of observation is marked by sudden swings of market confidence in all five countries, causing frequent spikes of both the distance to distress and CDS series. Market turbulence was particularly high during the $2008 / 2009$ global financial crisis, as is most visible on the Malaysia and Thailand charts.

Figure 4 also exhibits some correlations between the distance to distress and the CDS credit spreads. Previous conclusions are confirmed by correlation analysis summarized in Table 3. In levels, correlation between the two series is negative, because higher CDS spreads correlate to lower distance to distress. Except for Thailand, correlation is negative also in differences. That is, distance to distress tends to fall and CDS spreads increase when credit conditions deteriorate. Both in levels and in changes, correlation coefficients are highest for Indonesia and the Philippines, but their magnitude is still only moderate in general. The moderate correlation with CDS spreads is an indication that the debt sustainability information inferred from the CCA is only partly explained by the market perception of risks on sovereign debt reflected in the CDS spreads.

Table 3: Correlation of 5-Year CDS Spreads with Distance to Distress

\begin{tabular}{lccccc}
\hline & Indonesia & $\begin{array}{c}\text { Republic of } \\
\text { Korea }\end{array}$ & Malaysia & Philippines & Thailand \\
\hline Level & -0.43 & -0.12 & -0.18 & -0.36 & 0.15 \\
1-month change & -0.20 & 0.23 & -0.02 & -0.26 & -0.07 \\
3-month change & -0.34 & 0.10 & -0.04 & -0.36 & -0.12 \\
\hline First month & $31-$ Jan-06 & $31-$ Dec-11 & $31-$ - $c$-04 & $31-$ Jan-11 & 31-Aug-02 \\
Last month & 31-Aug-15 & 30-Jun-15 & 30-Jun-15 & 31-Aug-15 & 31-Jul-15 \\
\hline
\end{tabular}

CDS $=$ credit default swap.

Notes: First row: correlation between the two series in level. Second row: correlation between the monthly changes of the variables. Third row: correlation between the 3-month changes in the variables.

Source: Authors' estimates.

\section{A. Sensitivity Analysis}

We next assess the sensitivity of the distance to distress measures to the introduction of three alternative shocks: (1) a $1 \%$ increase in $\mathrm{MO},(2)$ a $1 \%$ increase in the value of risky debt, and (3) a $1 \%$ increase in the domestic liabilities volatility. Table 4 summarizes these shocks' impact on the distance to distress measure, while the broader impacts on sovereign balance sheets are contained in Appendix 1. 
Table 4: Sensitivity of the Distance to Distress to Three Alternative Scenarios

\begin{tabular}{|c|c|c|c|c|}
\hline & Baseline & $\begin{array}{c}\text { Scenario 1: } \\
1 \% \text { increase in } \\
\text { MO }\end{array}$ & $\begin{array}{l}\text { Scenario } 2: \\
1 \% \text { increase in } \\
\text { foreign debt }\end{array}$ & $\begin{array}{l}\text { Scenario } 3: \\
1 \% \text { increase in } \\
\text { LCL volatility }\end{array}$ \\
\hline \multicolumn{5}{|l|}{ Indonesia } \\
\hline Distance to distress & 6.84 & 6.85 & 6.82 & 6.23 \\
\hline Change in distance to distress & & 0.01 & -0.02 & -0.61 \\
\hline \multicolumn{5}{|l|}{ Republic of Korea } \\
\hline Distance to distress & 17.45 & 17.45 & 17.41 & 16.00 \\
\hline Change in distance to distress & & 0.01 & -0.04 & -1.44 \\
\hline \multicolumn{5}{|l|}{ Malaysia } \\
\hline Distance to distress & 6.26 & 6.27 & 6.25 & 5.75 \\
\hline Change in distance to distress & & 0.00 & -0.02 & -0.52 \\
\hline \multicolumn{5}{|l|}{ Philippines } \\
\hline Distance to distress & 12.71 & 12.72 & 12.69 & 10.21 \\
\hline Change in distance to distress & & 0.01 & -0.02 & -2.50 \\
\hline \multicolumn{5}{|l|}{ Thailand } \\
\hline Distance to distress & 19.30 & 19.32 & 19.25 & 17.32 \\
\hline Change in distance to distress & & 0.02 & -0.05 & -1.98 \\
\hline
\end{tabular}

$\mathrm{LCL}=$ local currency liability.

Source: Authors' estimates.

The first column Table 4 reports the baseline distance to distress, which at 17.45 standard deviations is highest for the Republic of Korea and lowest for Malaysia at 6.26. When shocked, distance to distress is largely insensitive to a $1 \%$ increase in base money or foreign debt, shown in the second and third columns. By contrast, the distance to distress is significantly shortened by a $1 \%$ increase in volatility of domestic liabilities, shown in the fourth column. For example, the measure falls by 0.52 standard deviation or $8.3 \%$ from the baseline for Malaysia and by 2.50 standard deviation or $19.7 \%$ for the Philippines. Additional simulations confirm that distance to distress reacts strongly to changes in returns' volatility and not to the other shocks envisaged. For example, raising foreign debt by as much as $10 \%$ causes Malaysia's distance to distress to drop by just about a third of its reaction to a $1 \%$ rise in asset volatility.

\section{B. Scenario Analysis: Implications of Exchange Rate Uncertainty}

Sensitivity analysis in the previous section is based on daily frequency data. Here, for an impact analysis of exchange rate uncertainty, we focus on annual aggregates and apply the CCA analysis to assess annual movements of the distance to distress, given the probability distribution of the future exchange rate for each of the five economies. 


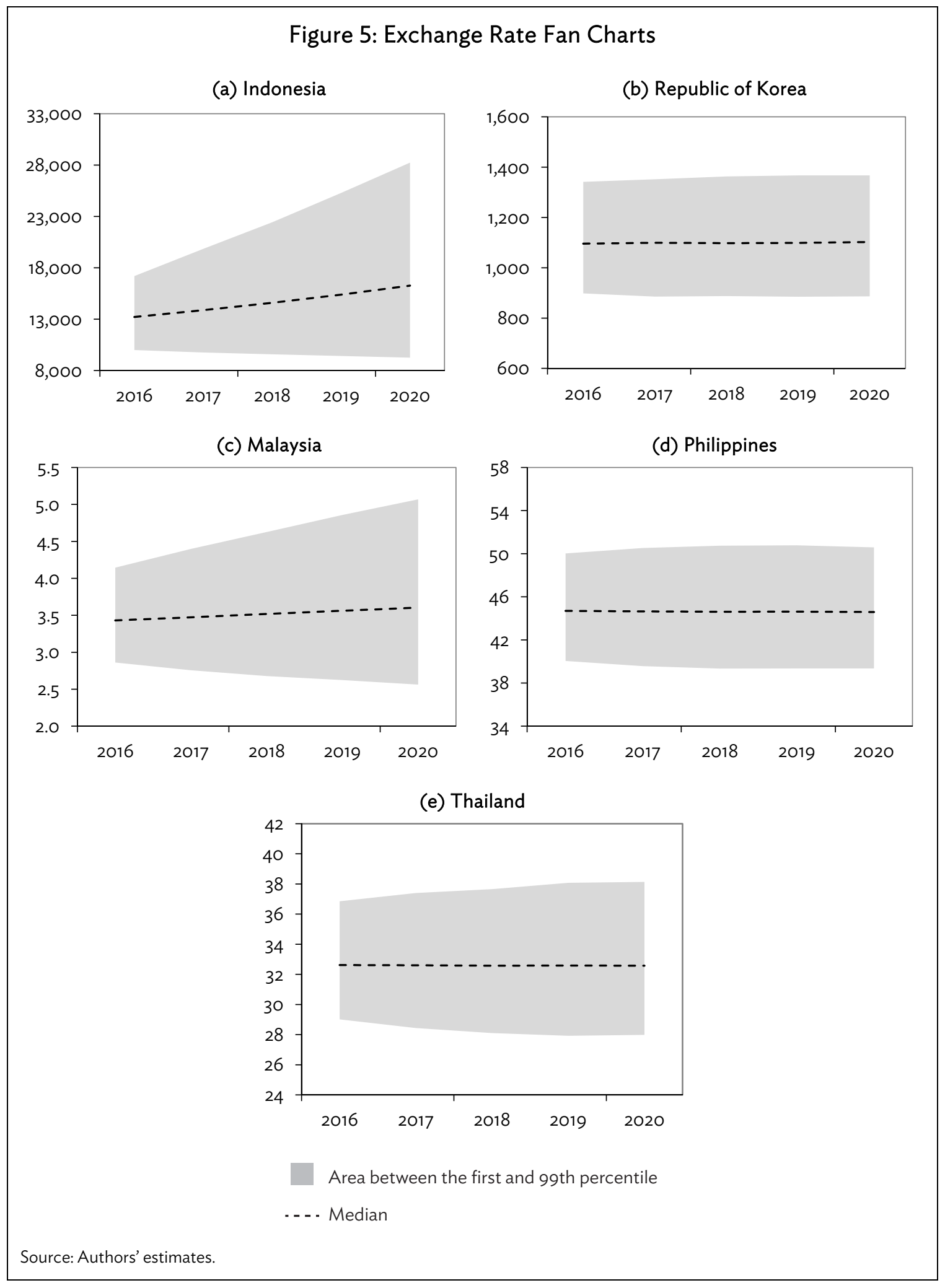


We first bootstrap the exchange rate projection five years ahead in order to get a probability distribution that is historically consistent. ${ }^{10}$ This yields exchange rate fan charts for the five countries, shown in Figure 5. Assuming a fixed value of domestic local currency liabilities, the exchange rate distribution translates to a distribution of domestic liabilities in foreign currency terms, according to equation (1). It also translates to the distribution of sovereign asset values, which we can then use in equation ( $2 a$ ) and (2b) to derive the distribution of the distance to distress for each of the five countries, assuming that foreign debt, the foreign interest rate and the volatility of sovereign assets returns are constant.

Figure 6 shows the resulting distance to distress country charts. The heightened exchange rate uncertainty, that is mostly visible in Indonesia and Malaysia, tends to have a moderate impact on the cross-sectional dispersion of the distance to distress. This is because, in our simulations, higher uncertainty about countries' exchange rates translates into greater cross sectional dispersion of the foreign currency value of the sovereign assets but is assumed to have no impact on the time-series volatility of the exchange rate, the variable the distance to distress is the most sensitive to. As a result, none of the countries is pushed into breaching the threshold of no distress.

Among the five countries analyzed, Indonesia appears most vulnerable to exchange rate shocks. Even in this case, the distance to distress is seen dropping only slightly. Far from breaching the threshold, distance to distress falls to no less than about 6.5 standard deviations by the end of the projection period.

However, it should be noted that changes in the value of foreign exchange rates likely affect also the volatility of the foreign currency value of sovereign asset returns. In other words, by way of the central CCA assumptions, the projected distribution of future exchange rate values should imply variations in asset returns volatility as well. Departing from the analysis hitherto as regards the computation of the volatility of asset returns, and in the light of a lack of daily forecast figures, we now measure the volatility as the standard deviation of changes to yearly asset returns, based on the projected value of the sovereign assets distribution.

Experimenting with this hypothesis, Figure 7 presents the outcome of simulation for Indonesia. Changes in the asset returns volatility due to exchange rate variations are now seen affecting Indonesia's distance to distress. Over the time span of simulation, this distance shortens from about 7 to 3 standard deviations. Although the effect of exchange rate uncertainty is now more pronounced, the country remains at a considerable length from breaching the threshold. The scenario analysis now shows how exchange rate fluctuations can act as a main factor of vulnerability affecting a country's distance to distress.

10 The annual forecast distribution is generated by annualizing a 10,000 random draw of quarterly exchange rate projections obtained from an AR(1) estimate for each economy. 
14 | ADB Economics Working Paper Series No. 486

Figure 6: Distance to Distress Distribution Due to Exchange Rate Variation

(a) Indonesia

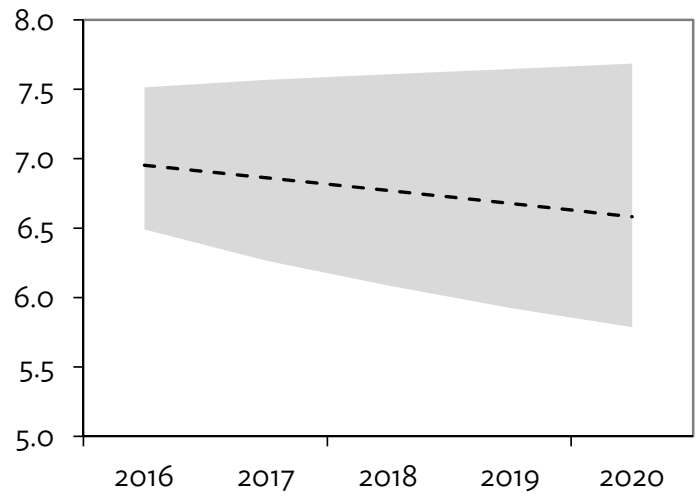

(c) Malaysia

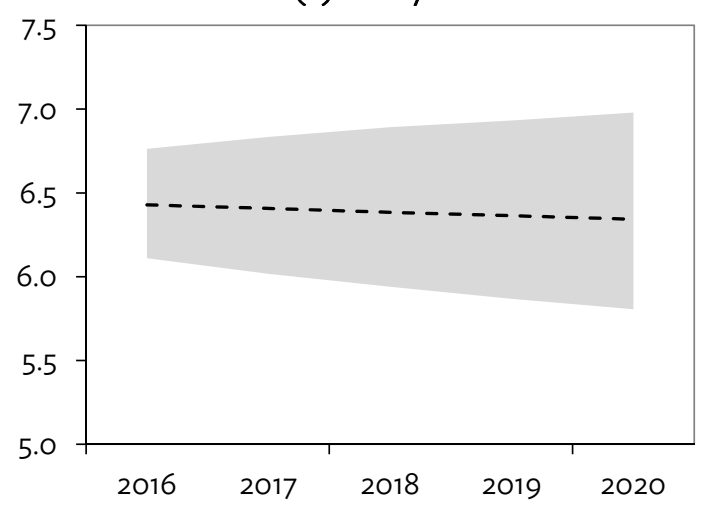

(b) Republic of Korea

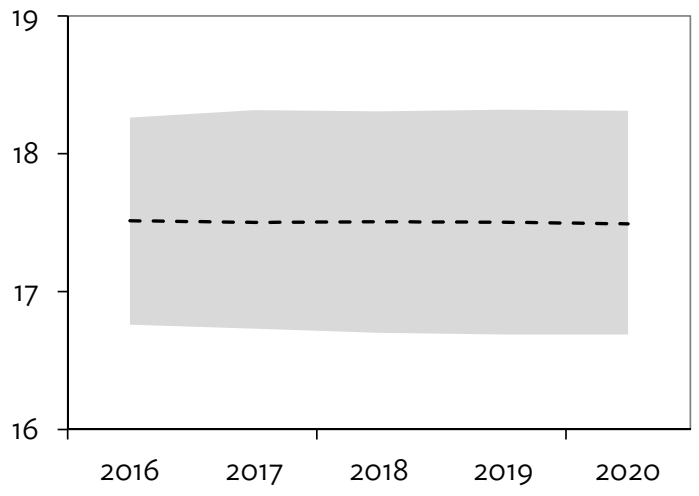

(d) Philippines

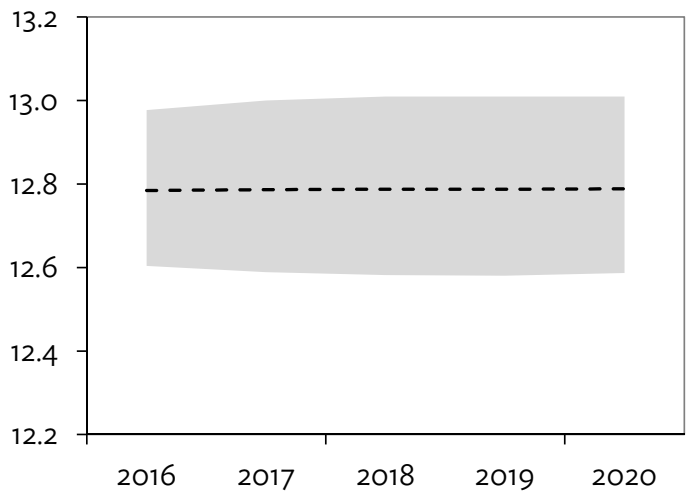

(e) Thailand

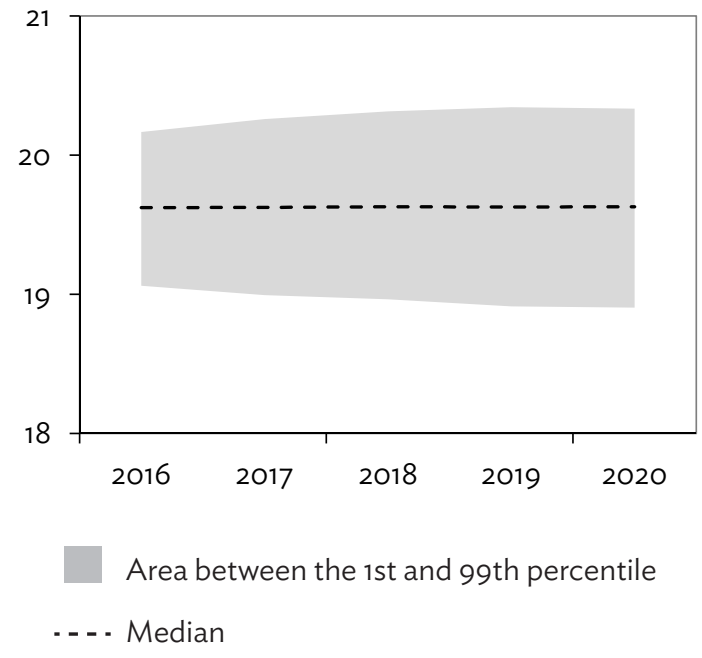

Source: Authors' estimates 


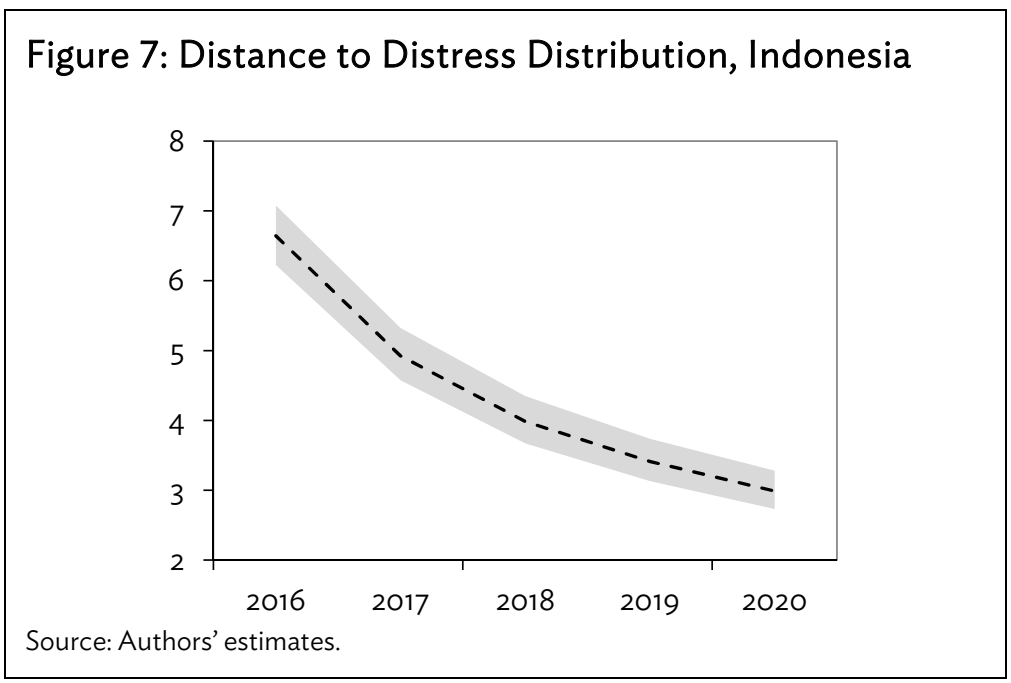

\section{CONCLUSION}

We apply contingent claims analysis to Indonesia, Malaysia, the Philippines, the Republic of Korea, and Thailand. We find that none of them would appear to be particularly vulnerable to sovereign debt distress, not in normal times and not when facing the less favorable macroeconomic scenarios considered. However, CDS spreads and distance to distress are highly volatile throughout the period of observation and none of the countries considered is immune to sudden drops in market perception of risk as reflected in higher CDS spreads and eroding assets value. Indonesia, for example, saw its sovereign assets value drop close to just above two standard deviations of its repayment obligations amidst capital outflows, exchange rate depreciation, and heightened uncertainty caused by the 2013 US Fed taper tantrum.

The CCA distance to distress measure correlates with country CDS spreads. Sensitivity and scenario analysis offer useful tools to help identify some of the drivers responsible for movements in the CCA measure, as well as in CDS spreads by extension. However, a large portion of sovereign CDS volatility remains unexplained within the context of the CCA analytical framework and somewhat undermines its usefulness to explain significant swings in market perception of risk.

Notwithstanding such caveats, CCA does help pinpoint the sustainability of a sovereign's capacity to pay as inferred to by implied asset value and volatility. Given its data parsimony and computational simplicity, it represents a feasible addition to the practitioner's tool box, complementing macroeconomic and fiscal flow analysis of standard DSA with an instrument to gather and reflect market sentiment and conduct basic scenario analysis.

Further research would assess the feasibility to extend Asian countries' CCA to other sectors of the economy. Gray and Malone (2008) discuss various types of linkages between the sovereign balance sheet equations and the corporate, financial, household balance sheets, complemented by the foreign sector. In principle, these sector CCA balance sheets can be integrated into one economywide balance sheet with risk exposures across sectors, modeled as implicit put and call options. In practice, the construction of an economywide CCA balance sheet is limited by scarce data availability in the studied countries. 


\section{APPENDIX 1: SENSITIVITY ANALYSIS OF THE SOVEREIGN BALANCE SHEET AND DEBT SUSTAINABILITY INDICATORS}

Table A1.1: Indonesia

\begin{tabular}{lcccc}
\hline $\begin{array}{l}\text { Contingent claim sovereign balance } \\
\text { sheet (\$ billion) }\end{array}$ & Baseline & $\begin{array}{c}\text { Scenario 1: } \\
\text { 1\% increase in } \\
\text { M0 }\end{array}$ & $\begin{array}{c}\text { Scenario 2: } \\
\begin{array}{c}\text { 1\% increase in } \\
\text { foreign debt }\end{array}\end{array}$ & $\begin{array}{c}\text { Scenario 3: } \\
\text { 1\% increase in } \\
\text { LCL volatility }\end{array}$ \\
\hline Implied value of sovereign assets & 134.95 & 135.25 & 135.43 & 134.95 \\
Value of risky foreign currency debt & 47.88 & 47.88 & 48.35 & 47.88 \\
$\quad$ Distress barrier & 51.73 & 51.73 & 52.25 & 51.73 \\
PV of distress barrier & 47.88 & 47.88 & 48.35 & 47.88 \\
PV of expected loss & 0.00 & 0.00 & 0.00 & 0.00 \\
Value of local currency liabilities & 87.08 & 87.38 & 87.08 & 87.08 \\
Implied volatility of assets & $6.70 \%$ & $6.71 \%$ & $6.68 \%$ & $7.34 \%$ \\
\hline Credit risk indicators & & & & \\
\hline Distance to distress & 6.84 & 6.85 & 6.82 & 6.23 \\
Sensitivity - change in distance to distress & & 0.01 & -0.02 & -0.61 \\
\hline
\end{tabular}

$\mathrm{LCL}=$ local currency liability, $\mathrm{MO}=$ monetary base, $\mathrm{PV}=$ present value.

Notes: The baseline case corresponds to the estimation made in August 2015. The three alternative scenarios correspond to a $1 \%$ change in MO; the value of foreign debt (e.g., from 100 to 101 ); and LCL volatility (e.g., from 6\% to 7\%), respectively.

Source: Authors' estimates.

Table A1.2: Republic of Korea

\begin{tabular}{lcccc}
\hline $\begin{array}{l}\text { Contingent claim sovereign balance } \\
\text { sheet }(\$ \text { billion) }\end{array}$ & Baseline & $\begin{array}{c}\text { Scenario 1: } \\
\text { increase in } \\
\text { MO }\end{array}$ & $\begin{array}{c}\text { Scenario 2: } \\
\text { 1\% increase in } \\
\text { foreign debt }\end{array}$ & $\begin{array}{c}\text { Scenario 3: } \\
\text { 1\% increase in } \\
\text { LCL volatility }\end{array}$ \\
\hline Implied value of sovereign assets & 464.84 & 465.46 & 464.90 & 464.84 \\
Value of risky foreign currency debt & 5.87 & 5.87 & 5.92 & 5.87 \\
$\quad$ Distress barrier & 6.37 & 6.37 & 6.43 & 6.37 \\
PV of distress barrier & 5.87 & 5.87 & 5.92 & 5.87 \\
PV of expected loss & 0.00 & 0.00 & 0.00 & 0.00 \\
Value of local currency liabilities & 458.98 & 459.60 & 458.98 & 458.98 \\
Implied volatility of assets & $11.13 \%$ & $11.13 \%$ & $11.13 \%$ & $12.12 \%$ \\
\hline Credit risk indicators & \multicolumn{5}{|c}{} \\
\hline Distance to distress & 17.45 & 17.45 & 17.41 & 16.00 \\
Sensitivity - change in distance to distress & & 0.01 & -0.04 & -1.44 \\
\hline
\end{tabular}

$\mathrm{LCL}=$ local currency liability, $\mathrm{MO}=$ monetary base, $\mathrm{PV}=$ present value.

Notes: The baseline case corresponds to the estimation made in June 2015. The three alternative scenarios correspond to a $1 \%$ change in MO; the value of foreign debt (e.g., from 100 to 101); and LCL volatility (e.g., from 6\% to 7\%), respectively.

Source: Authors' estimates. 
Table A1.3: Malaysia

\begin{tabular}{lcccc}
\hline $\begin{array}{l}\text { Contingent claim sovereign balance } \\
\text { sheet (\$ billion) }\end{array}$ & $\begin{array}{c}\text { Scenario 1: } \\
\text { Baseline }\end{array}$ & $\begin{array}{c}\text { Scenario 2: } \\
\text { M0 }\end{array}$ & $\begin{array}{c}\text { Scenario 3: } \\
\text { increase in } \\
\text { foreign debt }\end{array}$ & $\begin{array}{c}\text { 1\% increase in } \\
\text { LCL volatility }\end{array}$ \\
\hline Implied value of sovereign assets & 138.46 & 138.65 & 138.94 & 138.46 \\
Value of risky foreign currency debt & 48.39 & 48.39 & 48.88 & 48.39 \\
$\quad$ Distress barrier & 52.55 & 52.55 & 53.08 & 52.55 \\
PV of distress barrier & 48.39 & 48.39 & 48.88 & 48.39 \\
PV of expected loss & 0.00 & 0.00 & 0.00 & 0.00 \\
Value of local currency liabilities & 90.06 & 90.26 & 90.06 & 90.06 \\
Implied volatility of assets & $7.41 \%$ & $7.41 \%$ & $7.38 \%$ & $8.06 \%$ \\
\hline Credit risk indicators & \multicolumn{5}{|c}{} \\
\hline Distance to distress & 6.26 & 6.27 & 6.25 & \\
Sensitivity - change in distance to distress & & 0.00 & -0.02 & -0.52 \\
\hline
\end{tabular}

$\mathrm{LCL}=$ local currency liability, $\mathrm{MO}=$ monetary base, $\mathrm{PV}=$ present value.

Notes: The baseline case corresponds to the estimation made in June 2015. The three alternative scenarios correspond to a $1 \%$ change in MO; the value of foreign debt (e.g., from 100 to 101); and LCL volatility (e.g., from 6\% to 7\%), respectively.

Source: Authors' estimates.

Table A1.4: Philippines

\begin{tabular}{lcccc}
\hline $\begin{array}{l}\text { Contingent claim sovereign balance } \\
\text { sheet (\$ billion) }\end{array}$ & Baseline & $\begin{array}{c}\text { Scenario 1: } \\
\text { increase in } \\
\text { MO }\end{array}$ & $\begin{array}{c}\text { Scenario 2: } \\
\text { 1\% increase in } \\
\text { foreign debt }\end{array}$ & $\begin{array}{c}\text { Scenario 3: } \\
\text { 1\% increase in } \\
\text { LCL volatility }\end{array}$ \\
\hline Implied value of sovereign assets & 63.70 & 63.85 & 64.16 & 63.70 \\
Value of risky foreign currency debt & 46.47 & 46.47 & 46.93 & 46.47 \\
$\quad$ Distress barrier & 50.21 & 50.21 & 50.71 & 50.21 \\
PV of distress barrier & 46.47 & 46.47 & 46.93 & 46.47 \\
PV of expected loss & 0.00 & 0.00 & 0.00 & 0.00 \\
Value of local currency liabilities & 17.24 & 17.38 & 17.24 & 17.24 \\
Implied volatility of assets & $1.11 \%$ & $1.12 \%$ & $1.10 \%$ & $1.38 \%$ \\
\hline Credit risk indicators & \multicolumn{5}{|c}{10.21} \\
\hline Distance to distress & 12.71 & 12.72 & & \\
Sensitivity - change in distance to distress & & 0.01 & -0.02 & -2.50 \\
\hline
\end{tabular}

$\mathrm{LCL}=$ local currency liability, $\mathrm{MO}=$ monetary base, $\mathrm{PV}=$ present value.

Notes: The baseline case corresponds to the estimation made in August 2015. The three alternative scenarios correspond to a $1 \%$ change in MO; the value of foreign debt (e.g., from 100 to 101); and LCL volatility (e.g., from $6 \%$ to $7 \%$ ), respectively.

Source: Authors' estimates. 
Table A1.5: Thailand

\begin{tabular}{lcccc}
\hline $\begin{array}{l}\text { Contingent claim sovereign balance } \\
\text { sheet }(\$ \text { billion) }\end{array}$ & Baseline & $\begin{array}{c}\text { Scenario 1: } \\
\text { increase in } \\
\text { MO }\end{array}$ & $\begin{array}{c}\text { Scenario 2: } \\
\text { 1\% increase in } \\
\text { foreign debt }\end{array}$ & $\begin{array}{c}\text { Scenario 3: } \\
\text { 1\% increase in } \\
\text { LCL volatility }\end{array}$ \\
\hline Implied value of sovereign assets & 88.18 & 88.51 & 88.20 & 88.18 \\
Value of risky foreign currency debt & 2.08 & 2.08 & 2.11 & 2.08 \\
$\quad$ Distress barrier & 2.25 & 2.25 & 2.27 & 2.25 \\
PV of distress barrier & 2.08 & 2.08 & 2.11 & 2.08 \\
PV of expected loss & 0.00 & 0.00 & 0.00 & 0.00 \\
Value of local currency liabilities & 86.10 & 86.42 & 86.10 & 86.10 \\
Implied volatility of assets & $8.63 \%$ & $8.64 \%$ & $8.63 \%$ & $9.61 \%$ \\
\hline Credit risk indicators & & & & \\
\hline Distance to distress & 19.30 & 19.32 & 19.25 & 17.32 \\
Sensitivity - change in distance to distress & & 0.02 & -0.05 & -1.98 \\
\hline
\end{tabular}

$\mathrm{LCL}=$ local currency liability, $\mathrm{MO}=$ monetary base, $\mathrm{PV}=$ present value.

Notes: The baseline case corresponds to the estimation made in July 2015 . The three alternative scenarios correspond to a $1 \%$ change in M0; the value of foreign debt (e.g., from 100 to 101); and LCL volatility (e.g., from 6\% to 7\%), respectively.

Source: Authors' estimates. 


\section{APPENDIX 2: CONTINGENT CLAIMS ANALYSIS FOR THE PEOPLE'S REPUBLIC OF CHINA}

Data issues largely undermine the reliability of distance to distress estimates for the People's Republic of China (PRC), which are therefore relegated to this appendix. For example, monthly data on the book value of PRC foreign debt is unavailable. Among the databases accessed for this study, only annual data on PRC foreign debt could be retrieved from the CEIC database, and even that series has many missing values. We decided to use instead the market value of foreign debt obtained from the JP Morgan debt indices. We derived the series by aggregating the market value of the JP Morgan EMBI global and the Euro EMBIG index, which is foreign debt issued by the Chinese government in US dollars and euro (we converted the latter into US dollars).

Table B1 summarizes the data underlying the PRC analysis and Table B2 plots the results. The PRC's distance to distress is extremely volatile, more so than its CDS spread pattern would suggest. This is because the market value of foreign currency debt derived from JP Morgan debt indices is more volatile than CEIC book values, which we had to drop due to data limitations. The high volatility of the distance to distress may also be partly caused by the limited volatility of US dollar-denominated local currency liabilities, because of the renminbi's peg to the US dollar.'

Table A2.1: PRC Summary Statistics

\begin{tabular}{llc}
\hline MO & Avg & 742.82 \\
$\$$ billion & St dev & 199.82 \\
Bd & Avg & 333.51 \\
$\$$ billion & St dev & 58.79 \\
Bf & Avg & 14.16 \\
\$ billion & St dev & 10.33 \\
& & \\
Bf/(M0+Bd) & Avg \% & 1.32 \\
CDS 5-year spread & Avg & \\
basis points & St dev & 94.82 \\
Interest rate & Avg & 36.67 \\
$\%$ & St dev & 3.56 \\
FX spot rate & Avg & 0.48 \\
value of $\$ 1$ & St dev & 6.49 \\
FX return & & 0.31 \\
& Avg & $0.1 \%$ \\
\hline First month & Volatility & $2.2 \%$ \\
Last month & & $31-J a n-08$ \\
\hline
\end{tabular}

$B d=$ the value of local debt, $B f=$ the value of foreign debt, $C D S=$ credit default swap, $\mathrm{FX}=$ foreign exchange, $\mathrm{MO}=$ monetary base, $\mathrm{PRC}=$ People's Republic of China.

Source: Authors' estimates.

1 The volatility of local currency liabilities averages about $4 \%$ for the PRC, which is considerably lower than that of other countries in the sample, such as about $12 \%$ in the case of Indonesia. 


\section{Table A2.2: Sensitivity Analysis of the Sovereign Balance Sheet and Debt Sustainability Indicators, People's Republic of China}

\begin{tabular}{|c|c|c|c|c|}
\hline $\begin{array}{l}\text { Contingent claim sovereign balance sheet } \\
\text { ( } \$ \text { billion) }\end{array}$ & Baseline & $\begin{array}{c}\text { Scenario 1: } \\
\text { 1\% increase in } \\
\text { MO }\end{array}$ & $\begin{array}{l}\text { Scenario } 2: \\
1 \% \text { increase in } \\
\text { foreign debt }\end{array}$ & $\begin{array}{l}\text { Scenario } 3: \\
1 \% \text { increase in } \\
\text { LCL volatility }\end{array}$ \\
\hline Implied value of sovereign assets & $1,393.04$ & $1,402.30$ & $1,393.45$ & $1,393.04$ \\
\hline Value of risky foreign currency debt & 41.04 & 41.04 & 41.45 & 41.04 \\
\hline Distress barrier & 44.35 & 44.35 & 44.79 & 44.35 \\
\hline PV of distress barrier & 41.04 & 41.04 & 41.45 & 41.04 \\
\hline PV of expected loss & 0.00 & 0.00 & 0.00 & 0.00 \\
\hline Value of local currency liabilities & $1,352.00$ & $1,361.26$ & $1,352.00$ & $1,352.00$ \\
\hline Implied volatility of assets & $6.77 \%$ & $6.77 \%$ & $6.77 \%$ & $7.74 \%$ \\
\hline \multicolumn{5}{|l|}{ Credit risk indicators } \\
\hline Distance to distress & 23.20 & 23.23 & 23.14 & 20.27 \\
\hline Sensitivity - change in distance to distress & & 0.04 & -0.06 & -2.93 \\
\hline
\end{tabular}

$\mathrm{LCL}=$ local currency liability, $\mathrm{MO}=$ monetary base, $\mathrm{PV}=$ present value.

Notes: The baseline case corresponds to the estimation made in August 2015. The three alternative scenarios correspond to a $1 \%$ change in MO; the value of foreign debt (e.g., from 100 to 101); and LCL volatility (e.g., from $6 \%$ to 7\%), respectively.

Source: Authors' estimates.

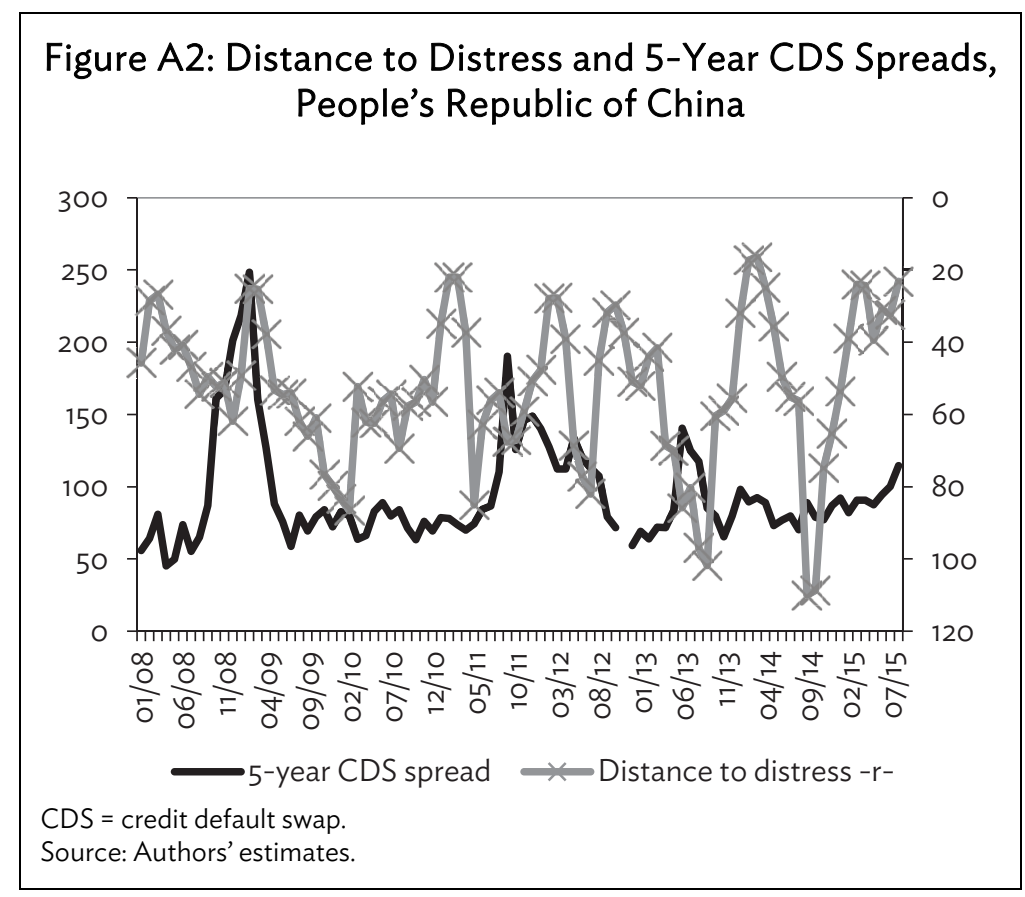




\section{APPENDIX 3: GUIDE TO CONTINGENT CLAIMS ANALYSIS DATA AND ESTIMATIONS}

The Microsoft Excel files underlying this paper are available upon request. They contain the data and CCA results for each of the five countries analyzed, plus the PRC. They provide guidance on to how to estimate the main items in the sovereign balance sheet, calculate the historical evolution of the debt sustainability indicators derived from contingent claims analysis, and perform scenario analysis. Each file contains four spreadsheets, providing the following information:

\section{A. Data and Local Currency Liability Volatility}

This spreadsheet contains all the data necessary for CCA analysis. It also computes the volatility of local currency liabilities.

1. The data series start in column $\mathrm{K}$. The series are clustered by source and are mostly raw data, with two exceptions:

(i) For MO, sourced from CEIC, both the monthly raw data and the daily interpolated data are provided. The linear interpolation was conducted in Eviews.

(ii) For the market value of foreign currency debt, sourced from JP MorganDatastream, the market values of debt in US dollars and in euro have been aggregated (euro debt was converted in US dollars and added to the US dollar debt.)

2. The calculation of volatility of local currency liabilities $(L C L)$ is located on the left side of the spreadsheet. The results are shown in the two columns colored in blue. Please note that:

(i) The first column computes daily rolling 1-month LCL volatility.

(ii) The second column computes daily rolling 3-month LCL volatility, which was used for the estimations.

(iii) To annualize the daily volatility measure, the standard deviation of returns is multiplied by the square root of 252 , which is the average number of trading days in 1 year.

\section{B. Contingent Claims Analysis Estimation}

This spreadsheet contains all the intermediate steps toward estimating the sovereign balance sheet items and the final debt sustainability indicators. Follow these four steps to run the calculations:

1. Columns B to I (in blue) are to be filled first with the necessary data (from spreadsheet $A$ )

2. Columns $A A$ to $A B$ (in blue) should be filled with initial values to help the convergence of the iteration process. To do so, copy and paste (paste special in values) the "initial values" in columns $Y$ and $Z$ of the spreadsheet, which provide initial estimations of the total value of the sovereign balance sheet and its volatility

3. Indicate the "start line" and "end line" of your calculation. Note that this will depend on the data availability for the various countries.

4. Push the "start" button in grey. It may take several minutes for the iterations to converge, to yield the final estimates of the total value of the sovereign balance sheet, its volatility and the debt sustainability indicators. Graphs are provided at the right-hand side of the spreadsheet. 


\section{Sensitivity Analysis}

This spreadsheet checks the results for their sensitivity to various scenarios. Starting from the baseline scenario corresponding to the last historical data available (line 15), three alternative scenarios are analyzed, each corresponding to a $1 \%$ increase in:

1. MO

2. the value of foreign debt, $B f$

3. the volatility of the local currency liabilities, Bd

This spreadsheet allows for any kind of scenario analysis, simply by changing the input parameters (columns $\mathrm{B}$ to $\mathrm{H}$ ) and rerunning the estimation.

The structure of this spreadsheet is identical to that of spreadsheet B (CCA estimation). Hitting the grey button will compute debt sustainability indicators based on the new hypotheses specified, following the same steps as in section (B). Before that, remember to copy and paste the "initial values" (columns $Y$ and $Z$ ) into columns AA and AB.

\section{Output}

This spreadsheet summarizes the main results in the form of:

1. a table summarizing the main items in the sovereign balance sheet estimation and the results of the sensitivity analysis, and

2. a graph comparing the historical evolutions of the distance to default to the CDS spread. 


\section{REFERENCES}

Adrogue, R. 2005. Fiscal Sustainability: A Value-at-Risk Approach. In M. Rodlauer and A. Schipke, Central America: Global Integration and Regional Cooperation. Occasional Paper 243, Washington, DC: International Monetary Fund.

Barnhill, T., and G. Kopits. 2003. Assessing Fiscal Sustainability under Uncertainty. IMF Working Paper WP/03/79. Published in 2004. Assessing Fiscal Sustainability under Uncertainty. Journal of Risk. 6 (4). pp. 31-53.

Black, F., and M. Scholes. 1973. The Pricing of Options and Corporate Liabilities. Journal of Political Economy. 81 (3). pp. 637-54.

Bodie, Z., and M. Brière. 2014. Sovereign Wealth and Risk Management: a Framework for Optimal Asset Allocation of Sovereign Wealth. Journal of Investment Management. 12 (1). pp. 45-61.

Crosbie, P., and J. Bohn. 2003. Modeling Default Risk. Moody's KMV.

Da Costa, E., A. Caputo Silva, and W. Baghdassarian. 2004. Assessing Three Models for the Analysis of Debt Sustainability. Getulio Vargas Foundation. Unpublished.

Duyvesteyn, J., and M. Martens. 2015. Forecasting Sovereign Default Risk with Merton's Model. Journal of Fixed Income. 25 (2). pp. 58-71.

Eaton, J., and M. Gersovitz. 1981. Debt with Potential Repudiation: Theoretical and Empirical Analysis and Estimation. Review of Economics Studies. 48 (2). pp. 289-309.

Ferrarini, B., and A. Ramayandi. 2015. Public Debt Sustainability in Developing Asia-An Update. ADB Economics Working Papers Series No. 468. Manila: Asian Development Bank.

Gray, D. F., and S. Malone. 2008. Macrofinancial Risk Analysis. United Kingdom: Wiley Finance.

Gray, D. F., R. C. Merton, and Z. Bodie. 2007. Contingent Claim Approach to Measuring and Managing Sovereign Credit Risk. Journal of Investment Management. 5 (4). pp. 1-24.

International Monetary Fund (IMF). 2002. Sovereign Debt Restructurings and the Domestic Economy Experience in Four Recent Cases. IMF Report prepared by the Policy Development and Review Department in consultation with other Departments. Approved by Mark Allen. https://www.imf.org/external/NP/pdr/sdrm/2002/022102.pdf

Kopits, G., B. Ferrarini, and A. Ramayandi. 2016. Exploring Risk-Adjusted Fiscal Sustainability Analysis for Asian Economies. ADB Economics Working Papers Series No. 483. Manila: Asian Development Bank.

Merton, R. C. 1973. Theory of Rational Option Pricing. Bell Journal of Economics and Management Science. 4 (1). pp. 141-83.

1974. On the Pricing of Corporate Debt: The Risk Structure of Interest Rates. Journal of Finance. 29 (2). pp. 449-70. 
-1977. An Analytic Derivation of the Cost of Loan Guarantees and Deposit Insurance: An Application of Modern Option Pricing Theory. Journal of Banking and Finance. 1. pp. 3-11.

Rogoff, K. S. 2011. Sovereign Debt in the Second Great Contraction: Is This Time Different? NBER Reporter 2011 Number 3.

Sturzenegger, F., and J. Zettelmeyer. 2008. Haircuts: Estimating Investor Losses in Sovereign Debt Restructurings, 1998-2005. Journal of International Money and Finance. 27 (5). pp. 780-805. 


\section{Contingent Claims Analysis of Sovereign Debt Sustainability in Asian Emerging Markets}

Contingent claims analysis applied to Indonesia, Malaysia, the Philippines, the Republic of Korea, and Thailand shows no particular vulnerability to sovereign debt distress during recent years. However, the highly volatile "distance to distress" measure suggests that any of these countries may fall victim to a sudden loss in market confidence. For example, the value of Indonesia's sovereign assets dropped to just two standard deviations above its repayment obligations during the 2013 Fed taper tantrum, causing capital outflows and currency depreciation. Generally, we find that contingent claims analysis and market-based risk measures well complement conventional debt sustainability analysis for Asia.

\section{About the Asian Development Bank}

ADB's vision is an Asia and Pacific region free of poverty. Its mission is to help its developing member countries reduce poverty and improve the quality of life of their people. Despite the region's many successes, it remains home to the majority of the world's poor. $A D B$ is committed to reducing poverty through inclusive economic growth, environmentally sustainable growth, and regional integration.

Based in Manila, ADB is owned by 67 members, including 48 from the region. Its main instruments for helping its developing member countries are policy dialogue, loans, equity investments, guarantees, grants, and technical assistance. 